\title{
DEVELOPMENT OF GRINDING MACHINE SUTABLE FOR MANGO KERNEL
}

\section{Suliman $^{1}$, A.EL-R.; M.S. Omran ${ }^{2}$; M.A. Baiomy ${ }^{3}$ and H.M. Ahmed ${ }^{4}$ \\ ABSTRACT}

The grinding process of agricultural wastes is important process to produce pre-materials for many uses. The aim of this study was develop and evaluate the grinding machine performance suitable for mango kernels as hard wastes. The average of mango kernel per pulp ratio was

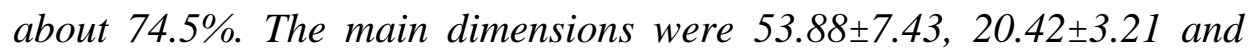
$10.98 \pm 1.89 \mathrm{~mm}$ at length, width and thickness, respectively, The spherisity was $(75.5 \pm 20.39 \%)$, geometric $(4.1 \pm 1.25 \mathrm{~mm})$ and arithmetic $(28.43 \pm 3.01 \mathrm{~mm})$ diameters, surface area $\left(56.9 \pm 34.3 \mathrm{~mm}^{2}\right)$, coefficient of frictions on galvanized, iron black painted and iron sheet were about $0.649,0.577$ and 0.675 respectively, hardness $(444.64 \pm 118.24 N)$ and shear strength $(224.62 \pm 98.65 N)$. The studied factories include feeding quantity " $F$ " of 10, 15 and 20kg, drum speeds "S" at 1500, 2000, 2500 and $3000 \mathrm{rpm}$ (28.26, 37.68, 47.10 and $56.52 \mathrm{~m} / \mathrm{s}$ ) and knives number " $N$ " of 24, 36 and 48 knives. The grinding machine performance was estimated by determine the product quality (grinding residual distribution and mean weight diameters "MWD") and the machine performance (machine productivity, power consumed and energy requirement). From the obtained results it can be concluded that the grinding machine can be manufactured and used to grinding the local mango kernel at the feeding quantity of $20 \mathrm{~kg}$, drum speed of $2000 \mathrm{rpm}$ and knives number of 36 to obtain the homogeneous size distribution with less " $C V$ " of 4.3, 11.22 and $12.26 \%$ respectively and at these studied parameters the MWD machine productivity, power consumed and specific energy requirement are $1.309 \mathrm{~mm}, 2.94 \mathrm{Mg} / \mathrm{h}, 3.60 \mathrm{~kW}$ and $1.22 \mathrm{~kW} . \mathrm{h} / \mathrm{Mg}$ respectively. The developed grinding machine which manufacture from a locally materials can be tested to grind many solid wastes to increase the developed grinding machine reliability.

\footnotetext{
${ }^{1}$ Prof, Agric. Eng. Dep., Fac. Agric., Cairo Univ. Egypt.

${ }^{2}$ Assoc. Prof. Agric. Eng., Fac. Agric., Cairo Univ. Egypt.

${ }^{3}$ Chief Res, Tech. Trans. Res. Dep., (AENRI) Ministry of Agriculture.

${ }^{4}$ Agric. Eng., Tech. Trans. Dep., (AENRI) Ministry of Agriculture
} 


\section{INTRODUCTION}

$\mathrm{G}$ rinding process is one of the basic operations dealing with agricultural wastes to reduce the volume of waste in order to facilitate trading, transportation and manufacturing process for processes for preparation of the product. El-Dorghamy (2010) estimated that the amount of agricultural waste in Egypt ranges from 30 to 35 million tons. Some of the agricultural waste is used as animal fodder, wood manufactured and biogas production. Campbell (2007) said that the quantity of crop residues in Egypt was 40 million ton/year, beside 8 million ton/year of horticultural according to the statistical survey of the Egyptian Ministry of Agriculture (2012). Egypt produces about 534.434 tons of mangoes annually (Central Administration for orchards and crops 2010).which yield about 240 thousand tons of seeds. Soong and Barlw (2006), Maisuthisakul and Gordon (2009) and Kim et al. (2010) reported that the mango seed represents from $20 \%$ to $60 \%$ of the whole fruit weight, depending on the mango variety and the kernel inside the seed which represents from $45 \%$ to $75 \%$ of the whole seed. In the food processing industry, considerable quantity of seed is discarded as waste, after the extraction of mango pulp. Mango seed kernel is a good source of phenolic antioxidants, metal chelators and tyrosinase inhibitors. Mahmoued (2005) analyzed the seed kernels of mango (Mangifera indica local variety) and reported that the seed kernels contained $12 \%$ moisture, $4.1 \%$ protein, $7.6 \%$ lipid, $75.5 \%$ carbohydrate, $10.3 \%$ crude fiber, $2.5 \%$ ash , $0.3 \%$ tannins. of $\mathrm{K}(16.8), \mathrm{Na}$ (7.6), Ca (3.5), P (0.30) $\mathrm{mg} / 100 \mathrm{~g}$. The advantage of mango kernels can be used as sweets flavor (Ashoush and Gad-Alla, 2011), poultry feed (Diarra, et al., 2011), and ruminants feed (Aregheor, 1998) and silage (Naveen, et al., 2006). The all uses of mango kernels should change it to particles by grinding or crushing machine. Hall and Davis (1979) classified mill equipments which for mango kernel size reduction into four types: Hammer mill, burr mill, combination mill and roller mill .Hammer mill consists of fixed or swinging hammers mounted on rotating shaft, screen and fan. These hammers are 2.5 to $7.5 \mathrm{~cm}$ ( 1 to 3 in) apart and rotate at 2500 to 4000 rpm depending on the diameter of hammers. Aly and Dimian (1988) and El-Hadidi et al. (1997) reported that power requirement and milling 
capacity are affected by material, moisture content, fineness of grinding, rate of feed and type mill. They added that hammer mill reduces the size by impact, while burr (plate) mill reduces the size by crushing and shear forces. They concluded that no significant differences were found between mills with respect to fineness degree while Medium fineness degree of $(3.0-4.2 \mathrm{~mm})$ was increased using burr mill and hammer mill compared with other types of mills. Deaton et al. (1989) used hammer mill with a full- circle screen with $4.8 \mathrm{~mm}$ round hole. It was operated by a $14.9 \mathrm{~kW}$. motor rotated at approximately $3450 \mathrm{rpm}$. The particle size for corn processing with the hammer mill ranged from 0.81 to $0.87 \mathrm{~mm}$. El-Ashhab et al. (2003) used a swinging hammer mill for grinding corn, horse bean and date stones for feed ration.They found that energy required to grind one ton corn grains at $4000 \mathrm{rpm}$ was duplicated when replacing the screen hole diameter $7.5 \mathrm{~mm}$ with another one $3.6 \mathrm{~mm}$.SciTech Dictionary (2003) mentioned that conventional hammer mill is a device consisting of a rotating head with free-swinging hammers, which reduce rock, grains or similarly hard objects to a predetermined size through a perforated screen. Hammer mills are widely utilized in the agricultural, wood, mining and chemical industries. FAO (2006) reported that the Hammer mills are very common throughout Africa. As the name implies, hammers in the mill grind grains through impact. A hammer mill consists of a large cylinder with a horizontal shaft that drives a rotor with several rows of free-swinging hammers. The hammers rotate inside a perforated metal screen through which the flour is drawn. McCabe et al. (1993) reported that size reduction equipment was divided into crusher, grinders, ultra-fine grinders and cutting machines. On the other hand Sun (2002) said that the size of waste-materials is usually 10 to $30 \mathrm{~mm}$ after chipping and 0.2 to $2.0 \mathrm{~mm}$ after milling or grinding. Fife $\boldsymbol{e t}$ al. (2010) found that the grinding this is processing by which material is reduced in particle size by impact, shearing or attrition. Grinding is normally accomplished using a hammer mill, with particle size controlled by screen size, hammer mill size and moisture content of the grain. Grinding the most common, cheapest, and simplest method of grain processing.

The aim of the present study is to develop and evaluate the grinding machine performance suitable for mango kernels as hard wastes. 


\section{MATERIALS AND METHODS}

To achieve the goal of this study a grinding machine consists of feeding unit, suitable frame and power source was construction in Agricultural Engineering Research Institute (AEnRI) workshop (Fig1 and 2) for grinding mango kernel (Mangifera indica local variety) obtained from Farag Allah company through 2009-2010.

(1) Frame was fabricated from $50 \times 50 \times 5 \mathrm{~L} \mathrm{~mm}$ steel 37C.The frame dimensions are $680 \times 1150 \times 1000 \mathrm{~mm}$ length, width and height, respectively.

(2) Feeding unit was fabricated from steel sheets $2 \mathrm{~mm}$ thickness as trapezoid shaped. The feeding unit was supported from the down end with the frame inlet at 60 degree inclination angle by knuckle. The feeding unit dimensions are $745 \times 400 \times 265 \mathrm{~mm}$, length, width and height, respectively.

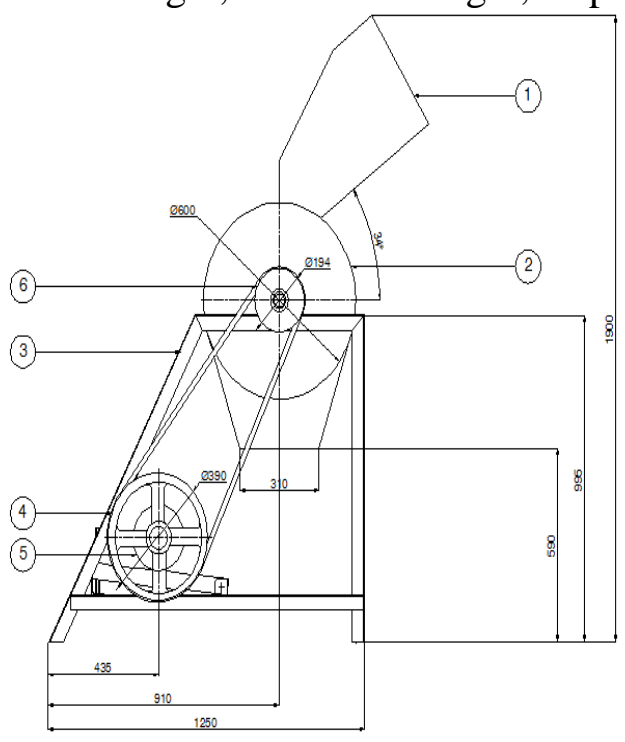

Fig.1: elevation view of the grinding machine.

1-Feed hopper 2-housing 3-frame

4-Motor pulley 5-Motor 6- Driving pulley

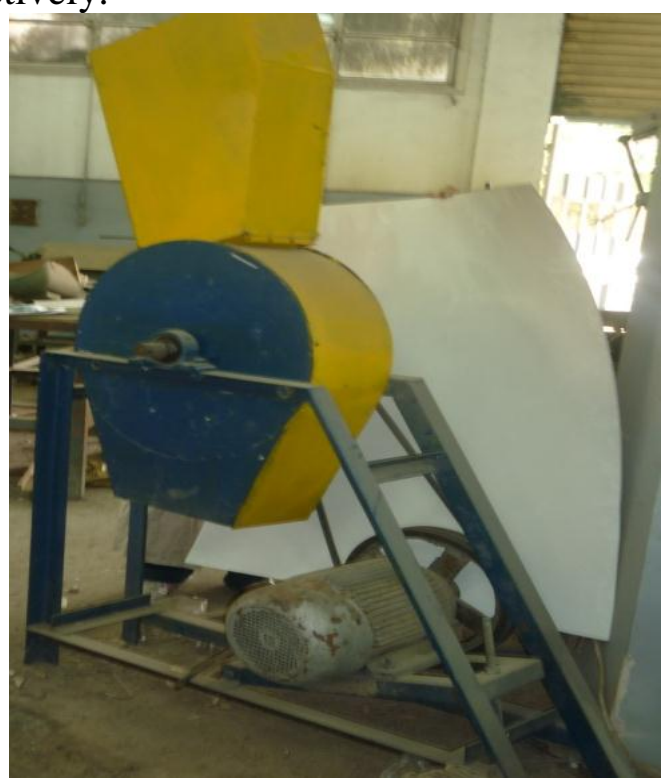

Fig.2: The grinding machine photographed.

(3) Grinding unit consists of:

- Case: It cylindrical shape with two opens; the inlet has dimensions of $300 \times 200 \mathrm{~mm}$ and the outlet open has dimensions of $310 \times 200 \mathrm{~mm}$ length and width, respectively.

- Drum consists of main shaft, four flanges and bins. 
- Knife made from spring steel with $100 \mathrm{~mm}$ length, $45 \mathrm{~mm}$ width and $8 \mathrm{~mm}$ thickness. The knives are mounting as a groups between the flanged each group include two knives.

- Screen holes is $6 \mathrm{~mm}$ and number of holes per square inch is 9 holes. The clearance between the knives and the screen is $10 \mathrm{~mm}$.

(4) Electrical motor of $3.677 \mathrm{~kW}$ (5 hp) was used to the grinding machine. The power was transmitted by pulley and belt.

The experiments were done in randomized complete block design at three replicates to determine the grinding machine performance under the studied factories. The following factories include:

1- Feeding quantity "F" (10, 15 and $20 \mathrm{~kg})$.

2- Drum speeds "S"(1500, 2000, 2500 and $3000 \mathrm{rpm})$.

3- Knives number "N" (24, 36 and 48 knives).

Experiments were done to show the effect of drum speeds "S", knives number "N" and feeding quantity "F" on the grinding machine performance. The grinding machine performance was estimated by determining the product quality (grinding residual distribution and mean weight diameters "MWD") and the machine performance (machine productivity, power consumed and energy requirement).

\section{Measurements}

\section{a. Mango kernels properties}

The length, width and thickness of 100 mango kernels measured by digital venire caliber with an accuracy of $0.05 \mathrm{~mm}$. Then the mango kernel properties are determined using the following equations (Mohsenin, 1998):

- Sphericity:

$$
\phi=\frac{D g}{\mathrm{~L}}=\frac{(\mathrm{L} \cdot \mathrm{W} \cdot \mathrm{T})^{1 / 3}}{\mathrm{~L}}
$$

Where: $\mathrm{Dg}=$ Geometric mean diameter, $\mathrm{mm}$

$\mathrm{L}$ = Mango kernel length, $\mathrm{mm}$

$\mathrm{W}=$ Mango kernel Width, $\mathrm{mm}$

$\mathrm{T}=$ Mango kernel thickness, $\mathrm{mm}$

- Geometric mean diameter $(\mathrm{Dg})$ and the arithmetic mean diameter (Da) (c.t. Seyed and Elnaz, 2006): 


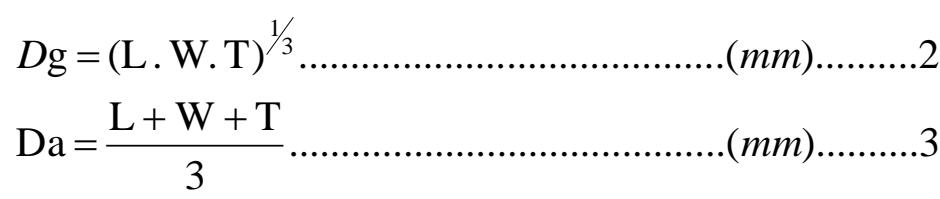

- Surface area (As):

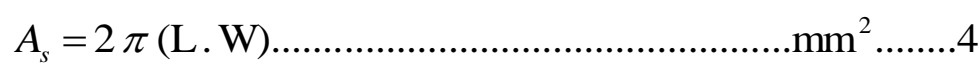

- Moisture content was determined by drying at $70^{\circ}$ (AOAC, 2000)

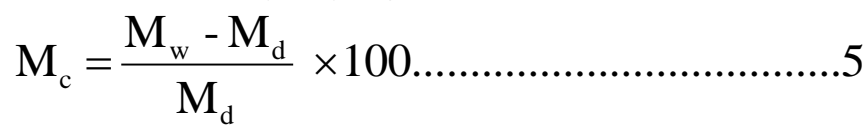

Where:

$$
\begin{aligned}
& \mathrm{M}_{\mathrm{c}}=\text { Mango kernel moisture content, \% } \\
& \mathrm{M}_{\mathrm{w}}=\text { Sample mass before drying }(\mathrm{g}) \\
& \mathrm{M}_{\mathrm{d}}=\text { Mass after drying sample }(\mathrm{g})
\end{aligned}
$$

- Percentage of kernels per pulp using 100 mango fruits. Was determined e following equation.

$$
\text { Mango kernel } \%=\frac{\text { Mango kernel weight }}{\text { Mango fruit weight }} \times 100
$$

- Kernel coefficient of friction was measured using measuring device on three surface iron black painted, iron and galvanized iron sheets. The angle of friction was measured and the coefficient of friction was calculated from the flowing equation. (Mohsenin , 1998)

$$
\mu=\tan \theta
$$

Where: $\mu=$ coefficient of friction.

$\theta=$ the friction angle.

- Hardness and shear strength was measured by the digital force gauge for ten kernels.

\section{b. Grinding machine performance}

\section{Product quality}

- Mean weight of diameters (MWD) were estimated by using the sieve apparatus. After sieving all the individual particles are weighed and all the portions are calculated according to RNAM (1983) to determine MWD:

$$
\mathrm{MWD}=\frac{1}{\mathrm{~W}}(3.35 \mathrm{~A}+1.4 \mathrm{~B}+1.5 \mathrm{C}+0.68 \mathrm{D}+\mathrm{NF})
$$


Where: $\mathrm{MWD}=$ Mean grinding mango kernel diameter, $\mathrm{mm}$

$\mathrm{W}=$ Weight of grinding crops residue $(\mathrm{A}+\mathrm{B}+\mathrm{C}+\mathrm{D}+\mathrm{F}), \mathrm{kg}$

$\mathrm{N}=$ Mean of measured diameters of grinding crops residue retained on the largest aperture sieve, $\mathrm{mm}$

- Grinding residual distribution of the output product was determined using three standard sieves (3.35, 1.40, 0.68 and <0.68) (ASAE, 2001). The total weight of samples and the mass of each product categories were weighed using a digital scale balance with an accuracy of $0.01 \mathrm{~g}$.

\section{Machine performance}

- Grinding machine productivity "Pr" was calculated using the following formula:

$$
P_{r}=\frac{W \times 3600}{t}, \mathrm{Mgh}^{-1}
$$

Where: $P \mathrm{r}=$ Productivity, $\mathrm{Mgh}^{-1}$.

$\mathrm{W}=$ Mass of the sample, $\mathrm{Mg}$.

$\mathrm{t}=$ Consumed time, $\mathrm{h}$

- consumed Power $(\boldsymbol{k W})$ was calculated using the following formula of: (Ibrahim, 1982)

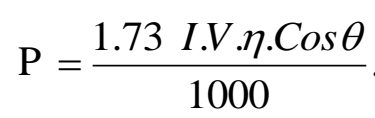

Where: $I=$ Line current strength in amperes.

$V=$ Potential difference (Voltage) being equal to $380 \mathrm{~V}$.

$\operatorname{Cos} \theta=$ Power factor (being equal to 0.84 ).

$\sqrt{3}=$ Coefficient current three phase (being equal 1.73).

$\eta=$ Mechanical efficiency assumed (95\%).

- Specific energy requirment (E) calculated using the ollowing equaion:

The specific energy requirement $=\frac{\text { The consumed power }(\mathrm{kW})}{\text { Actual capacity }(\mathrm{Mg} / \mathrm{h})}$

\section{c- Statistical analysis}

Microsoft Excel 2010 computer program was use to carry out the multiple regression analysis to represent the relation between each of MWD, machine productivity, consumed energy, power requirement and all of feeding quantity, drum speed and knives number. 


\section{RESULTS AND DISCUSSION}

\section{a- Mango kernels properties}

The average of mango kernel ratio was $74.5 \%$ from the mango seeds, while the seed casing is was $25.5 \%$. the mango kernel moisture content was $12.0 \%$. Figs ( 3 and5) illustrate the frequency of the main dimensions of mango kernel are $53.88 \pm 7.43,20.42 \pm 3.21$ and $10.98 \pm 1.89 \mathrm{~mm}$ at length, width and thickness, respectively. Some properties of mango kernels were measured and its results are tabulated in Table (1)

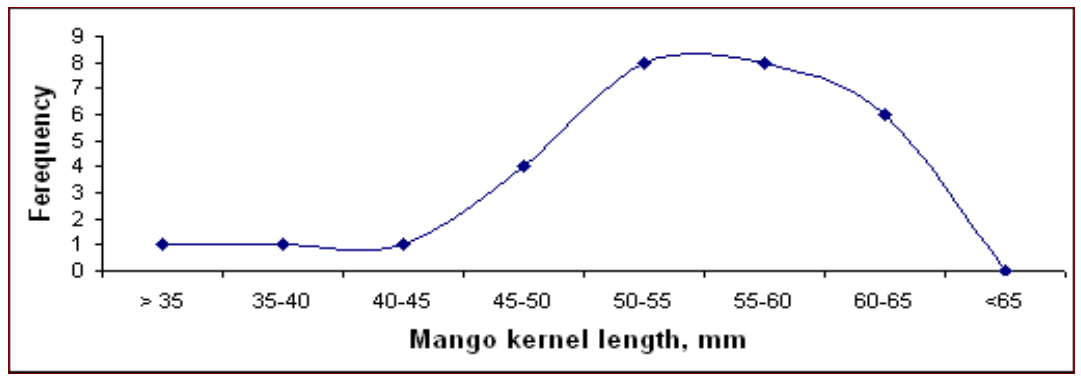

Fig. 3: The Mango kernel length frequency.

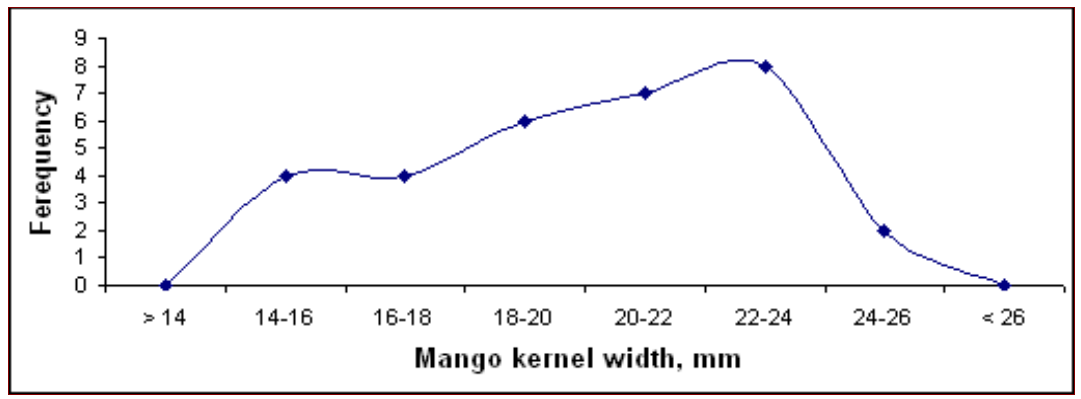

Fig. 4: The Mango kernel width frequency.

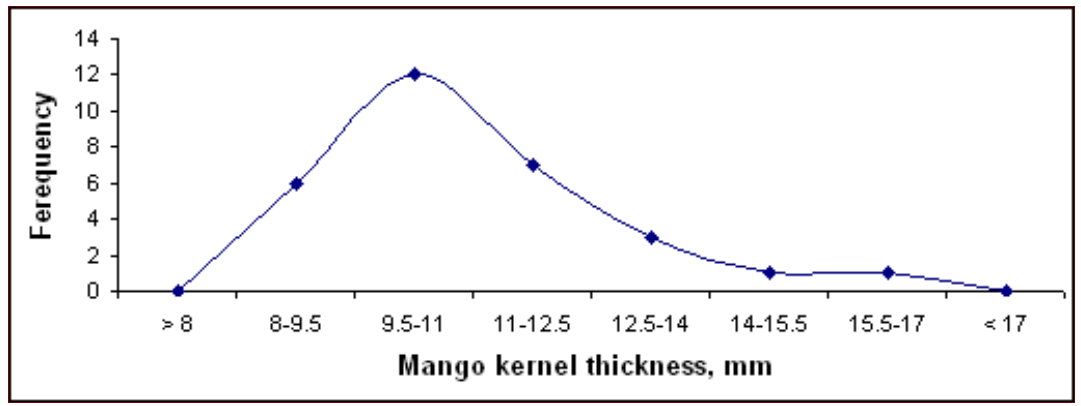

Fig. 5: The Mango kernel thickness frequency. 
Table 1: The mango kernel engineering properties

\begin{tabular}{|c|c|c|c|c|}
\hline Engineering properties & Mean ${ }^{ \pm S D}$ & Maximum & Minimum & $\mathrm{CV}, \%$ \\
\hline Spherisity, \% & $75.50^{ \pm 20.39}$ & 130.16 & 44.60 & 27.14 \\
\hline Geometric mean diameter, mm & $4.10^{ \pm 1.25}$ & 7.01 & 2.12 & 26.50 \\
\hline Arithmetic mean diameter, mm & $28.43^{ \pm 3.01}$ & 33.50 & 22.05 & 9.41 \\
\hline Surface area, $\mathbf{m m}^{2}$ & $56.93^{ \pm 34.3}$ & 19.75 & 11.56 & 13.54 \\
\hline \multicolumn{5}{|l|}{ Coefficient of friction } \\
\hline \multirow{3}{*}{$\begin{array}{l}\text { iron sheet galvanized } \\
\text { iron black painted } \\
\text { iron sheet }\end{array}$} & 0.649 & & & \\
\hline & 0.577 & & & \\
\hline & 0.6745 & & & \\
\hline Hardness & $444.64^{ \pm 118.24}$ & 594.00 & 243.10 & 31.46 \\
\hline Shear Strength & $224.62^{ \pm 98.65}$ & 399.00 & 125.50 & 78.65 \\
\hline
\end{tabular}

b. Grinding machine performance

1- Effect feeding quantity, drum speed and knives number on grinding residual distribution

Figs from (6) to (8) illustrate that the effect of studied variables on grinding residual distribution at different sieves hole diameters. From the figures it can be seen that by increase feeding quantity, drum speed and knives number the average of grinding residual decreased at sieves diameters of 3.35 and $1.4 \mathrm{~mm}$, while the inverse trend obtained at sieves diameters of 0.68 and $>0.68 \mathrm{~mm}$. Therefore, Fig. (6) shows that at feeding quantity of $10 \mathrm{~kg}$ the average of grinding residual distribution are $15.9,29.28,26.73$ and $28.08 \%$ respectively at sieves diameters of 3.35 , $1.40,0.68$ and $>0.68 \mathrm{~mm}$. Then the corresponding results at 15 and 20 $\mathrm{kg}$ feeding quantity are 16.94, 24.91, 27.96 and $30.19 \%$ and 13.55, 27.44, 29.85 and $29.16 \%$, respectively. On the other side, Fig.(7) cleared that the increase in drum speed from 1500 to $3000 \mathrm{rpm}$ the average of grinding residual distribution decrease from 18.91 to 10.11 and from 34.93 to $18.52 \%$, respectively at sieves hole diameters of 3.35 and $1.40 \mathrm{~mm}$. Contrary, the increase in drum speed from 1500 to 3000 $\mathrm{rpm}$ the average of grinding residual distribution increase from 24.16 to 28.83 and from 21.99 to $42.54 \%$ respectively at sieves hole diameters of 0.68 and $>0.68 \mathrm{~mm}$. However, Fig. (8) shows that the increase in knives number from 24 to 48 the average of grinding residual distribution decrease from 20.69 to 11.46 and from 34.52 to $22.55 \%$, respectively at 
sieves hole diameters of 3.35 and $1.40 \mathrm{~mm}$. On the opposite side, the increase in knives number from 24 to 48 the average of grinding residual distribution increase from 22.68 to 30.90 and from 22.11 to $35.08 \%$, respectively at sieves hole diameters of 0.68 and $>0.68 \mathrm{~mm}$. These results explain that the drum speed and the knives number are the effective variable on the grinding residual distribution while the feeding quantity is the less effect. The coefficient of variance for the grinding obtained from the sieves diameters ranging from 1.4 to $>0.68 \mathrm{~mm}$; according to Sun (2002); conducted that the lowest "CV" were 4.30, 11.21 and $12.26 \%$ obtained at feeding quantity of $20 \mathrm{~kg}$, drum speed of $2000 \mathrm{rpm}$ and knives number of 36 knife.

\section{2- Effect of studied variables on mean weight diameter (MWD)}

Fig. (9) cleared that the effect of drum speed on mean weight diameter at different knives number and feeding quantity. From the figure it can be seen that the grinding MWD has an inversally proportional to feeding quantity, drum speed and knives number. Meanwhile, the grinding MWD decreased from 1.49 to $1.12,1.42$ to 1.11 and 1.43 to $1.01 \mathrm{~mm}$ by increase the drum speed from 1500 to $3000 \mathrm{rpm}$ respectively at 10, 15 and $20 \mathrm{~kg}$ feeding quantity. In the same trend the grinding MWD decreased from 1.50 to $1.19,1.57$ to 1.14 and 1.37 to $1.14 \mathrm{~mm}$ by increase the knives number from 24 to 48 respectively at 10,15 and 20 $\mathrm{kg}$ feeding quantity. Therefore, at feeding quantity 10,15 and $20 \mathrm{~kg}$ the grinding MWD were 1.31, 1.30 and $1.25 \mathrm{~mm}$ respectively. These results trend is logically which clear the slightly effect of the decrese at the change of feeding quantity while the effect is incresed at changes the both of drum speed and knives number. Using the multiple regression analysis the relation between the all levels of feeding quantity " $F$ ", drum speed "S", knives number " $\mathrm{N}$ " and the grinding mean weight diameter (MWD) can be shown as the following linear regression equation:

$$
\text { MWD }=0.0431 \mathrm{~F}+0.0001 \mathrm{~S}+0.0073 \mathrm{~N} \quad\left(\mathrm{R}^{2}=0.9180\right)
$$

The analysis of variance for the data of MWD at different of feeding quantity, drum speed and knives number indicated a high significant between the treatments with $\left(R^{2}=0.9180\right)$. 


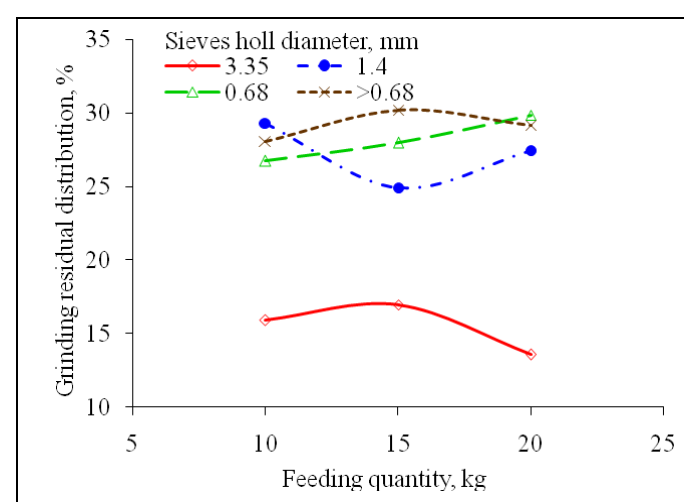

Fig. 6: Effect of feeding quantity on grinding residual distribution. Feeding quantity "kg"; 10

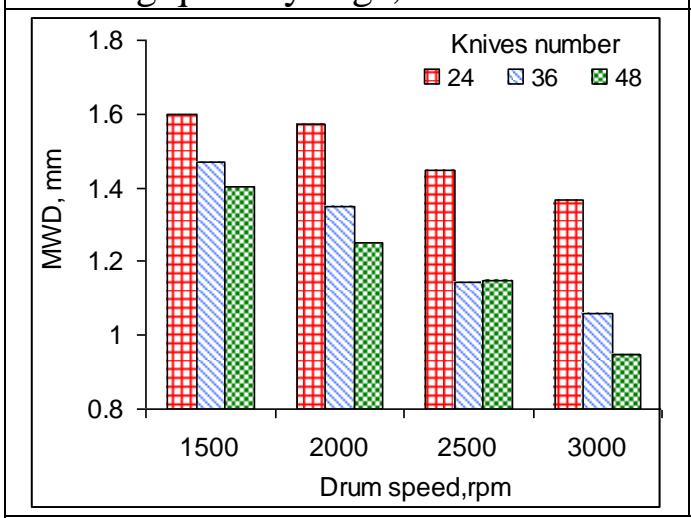

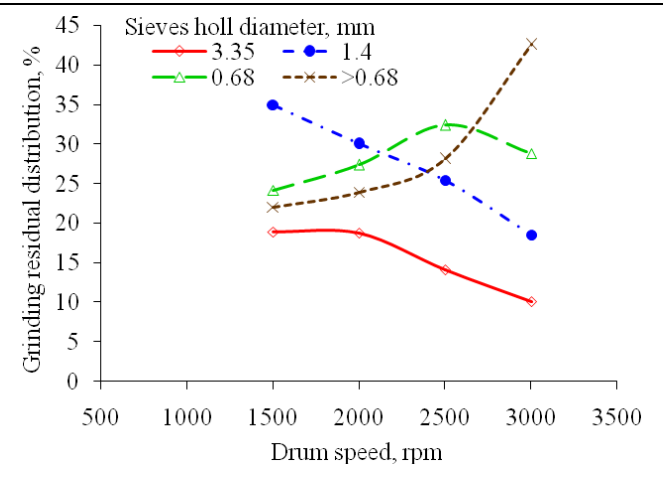

Fig. 7: Effect of drum speed on grinding residual distribution.

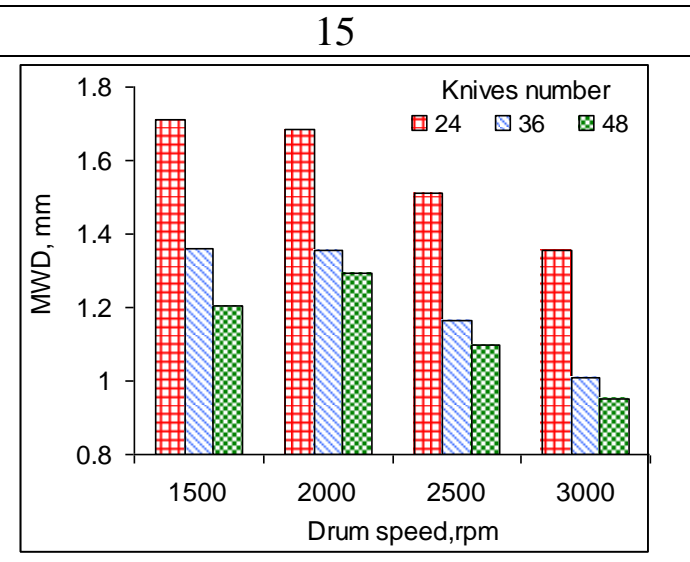

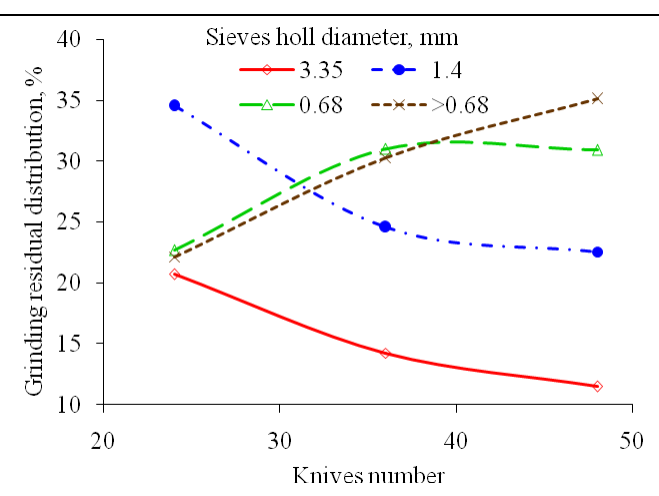

Fig. 8: Effect of knives number on grinding residual distribution.

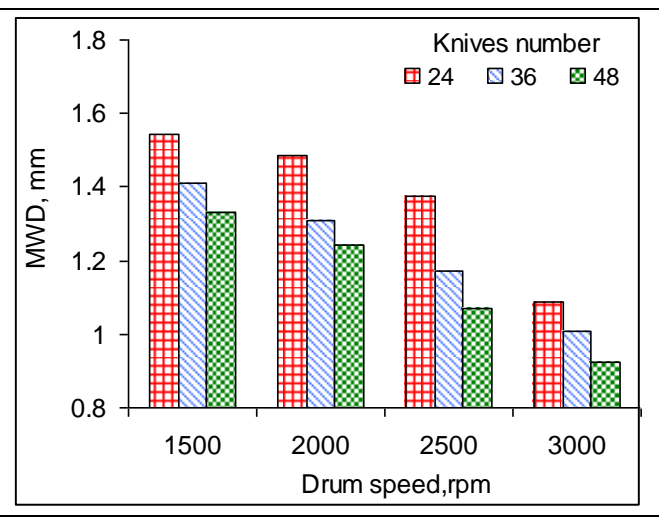

Fig. 9: Effect of drum speed on mean weight diameter at different knives number and feeding quantity. 


\section{3- Effect of studied variables on grinding machine productivity}

Fig. (10) describe that the effect of drum speed on grinding machine productivity at different feeding quantity and knives number. The figure clear that the grinding mchine prouctivity has a directly proportional to all levels of feeding quantity, drum speed and knives number. Moreover, the average of grinding machine productivity increased from 1.85 to $3.19 \mathrm{Mg} / \mathrm{h}$ by increasing the feeding quantity from 10 to $20 \mathrm{~kg}$ at neglected the both of drum speed and knives number. Hence the average of grinding machine productivity increased from , 2.40 to $2.64 \mathrm{Mg} / \mathrm{h}$ by increasing the drum speed from 1500 to $3000 \mathrm{rpm}$ at neglected both of the feeding quantity and knives number. Consequently, the average of grinding machine productivity increased from 2.10 to $3.01 \mathrm{Mg} / \mathrm{h}$ by increasing the knives number from 10 to $20 \mathrm{~kg}$ at neglected the bothe of feeding quantity and drum speed.

Using the multiple regression analysis the relation between the all levels of feeding quantity "F", drum speed "S", knives number "N" and the grinding machine productivity $(\mathrm{P})$ can be shown as the following linear regression equation:

$$
\mathrm{P}=0.000003 \mathrm{~F}+0.02465 \mathrm{~S}+0.11115 \mathrm{~N}
$$

The analysis of variance for the data of grinding machine productivity at different of feeding quantity, drum speed and knives number indicated a high significant between the treatments with $\left(\mathrm{R}^{2}=0.9832\right)$.

\section{4- Effect of studied variables on power consumed}

Fig. (11) explain that the effect of drum speed on power consumed at different knives number and feeding quantity. From the figure it can be seen that the power consumed has a directly proportional to feeding quantity, drum speed and knives number. Moreover, the power consumed increased from 4.32 to $9.59,4.66$ to 9.77 and 4.76 to $10.67 \mathrm{~kW}$ by increase the drum speed from 1500 to $3000 \mathrm{rpm}$, respectively at 10,15 and $20 \mathrm{~kg}$ feeding quantity. On the other hand, the power consumed increased from 2.575 to $11.135,2.712$ to 11.135 and 2.850 to $12.43 \mathrm{~kW}$ by increase the knives number from 24 to 48 , respectively at 10,15 and $20 \mathrm{~kg}$ feeding quantity. Then, at feeding quantity 10,15 and $20 \mathrm{~kg}$ the power consumed were 6.38, 6.51 and $7.03 \mathrm{~mm}$, respectively. 


\section{FARM MACHINERY AND POWER}

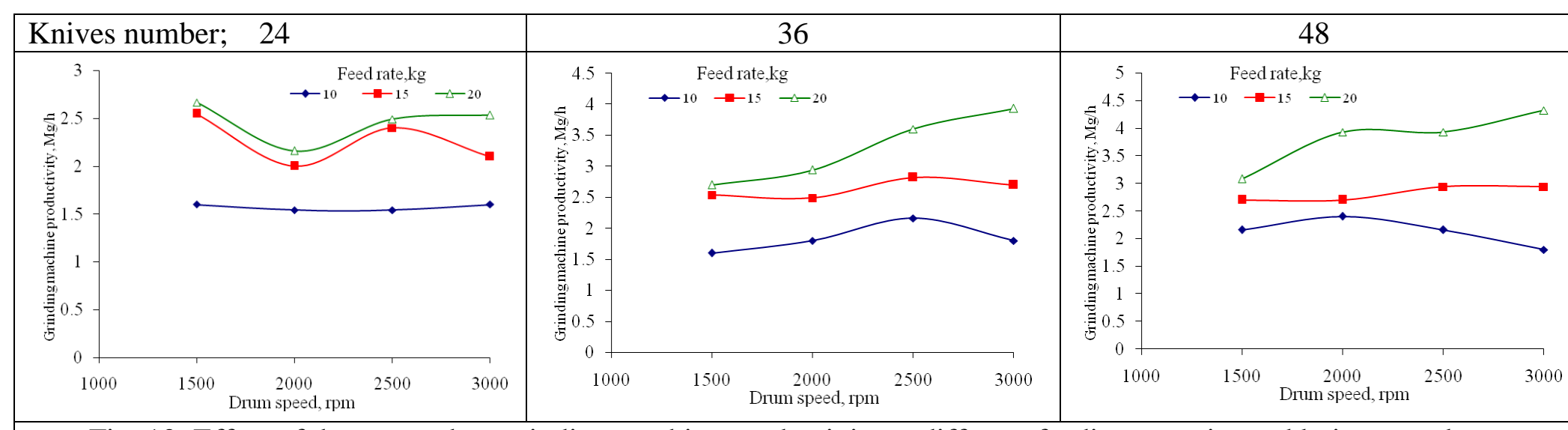

Fig. 10: Effect of drum speed on grinding machine productivity at different feeding quantity and knives number.
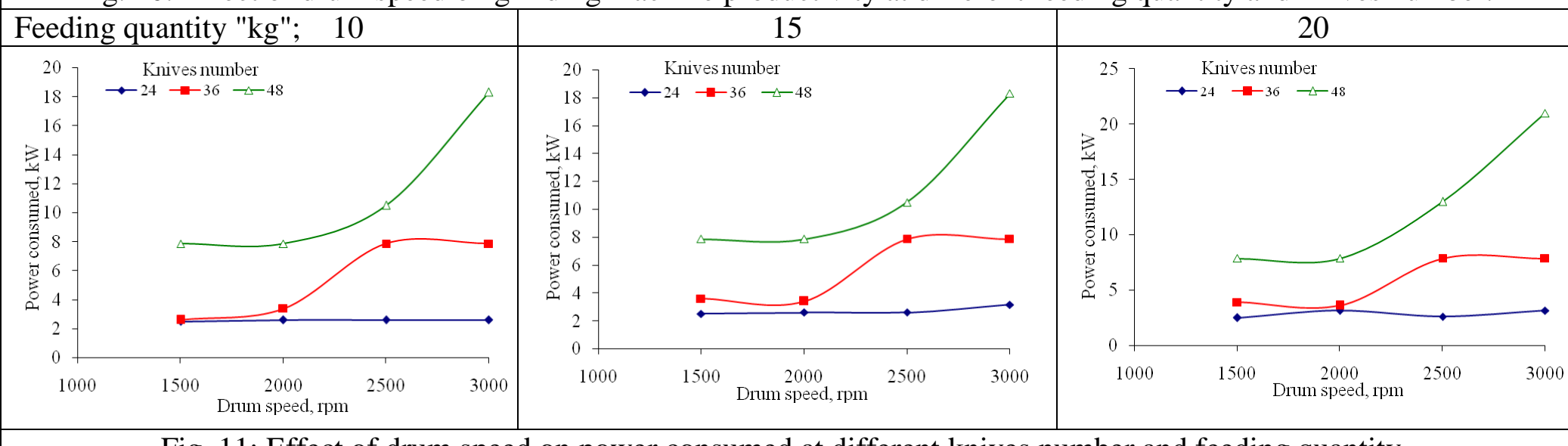

Fig. 11: Effect of drum speed on power consumed at different knives number and feeding quantity. 
Using the multiple regression analysis the relation between the all levels of feeding quantity "F", drum speed "S", knives number " $\mathrm{N}$ " and the power consumed $(\mathrm{P})$ can be shown as the following linear regression equation:

$$
\mathrm{Pw}=0.00115 \mathrm{~F}+0.2324 \mathrm{~S}-0.2629 \mathrm{~N} \quad\left(\mathrm{R}^{2}=0.8362\right)
$$

The analysis of variance for the data of power consumed at different of feeding quantity, drum speed and knives number indicated a high significant between the treatments with $\left(\mathrm{R}^{2}=0.8362\right)$.

\section{4- Effect of studied variables on specific energy requirement}

Fig. (12) cleared that the effect of drum speed on specific energy requirement at different knives number and feeding quantity. From the figure it can be shows that the specific energy requirementhas has a directly proportional to feeding quantity and drum speed on the opposite that trend found at knives number. On the other side, the average of specific energy requirement increased from 2.04 to $3.99 \mathrm{~kW}$.h/ton by increase the drum speed from 1500 to $3000 \mathrm{rpm}$, respectively. Moreover, the specific energy requirement decreased from 3.61 to $2.16 \mathrm{~kW} . \mathrm{h} /$ ton by increase the knives number from 24 to 48 , respectively. Then, the average of specific energy requirement increased from 1.23 to $3.52 \mathrm{~kW}$.h/ton by increase the feeding quantity from 10 to $20 \mathrm{~kg}$, respectively. Using the multiple regression analysis the relation between the all levels of feeding quantity " $F$ ", drum speed "S", knives number " $\mathrm{N}$ " and the specific energy requirement (E) can be shown as the following linear regression equation:

$$
\mathrm{E}=0.0009 \mathrm{~F}+0.0955 \mathrm{~S}-0.1872 \mathrm{~N} \quad\left(\mathrm{R}^{2}=0.8795\right)
$$

The analysis of variance for the data of specific energy requirement at different of feeding quantity, drum speed and knives number indicated a high significant between the treatments with $\left(R^{2}=0.8795\right)$. 


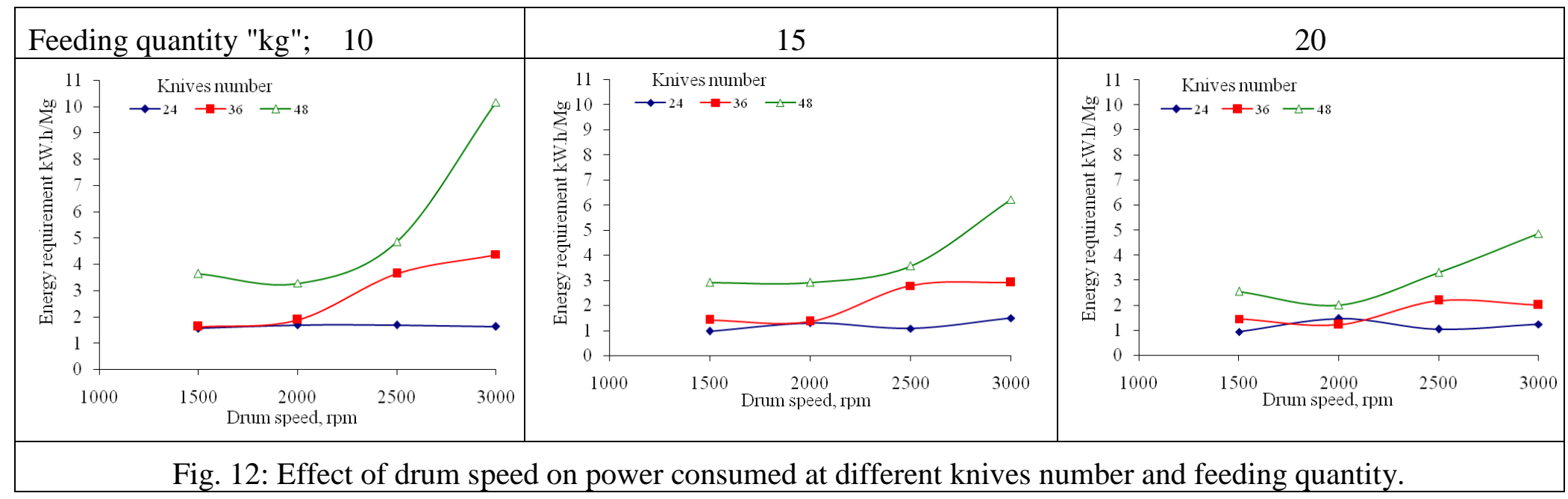




\section{CONCLUSIONS}

From the obtained results it can be concluded that:

1- The average of mango kernel ratio is about $74.5 \%$. Then the mango kernel moisture content is about $12.0 \%$. While the average main dimensions of mango kernel are 53.88 $\pm 7.43,20.42 \pm 3.21$ and $10.98 \pm 1.89 \mathrm{~mm}$ at length, width and thickness, respectively. Also, the average of spherisity $(75.5 \pm 20.39 \%)$, geometric $(4.1 \pm 1.25 \mathrm{~mm})$ and arithmetic $(28.43 \pm 3.01$ $\mathrm{mm}$ ) diameters, surface area $\left(56.9 \pm 34.3 \mathrm{~mm}^{2}\right)$, coefficient of frictions on galvanized, iron black painted and iron sheet were about $0.649,0.577$ and 0.675 respectively, hardness $(444.64 \pm 118.24 \mathrm{~N})$ and shear strength $(224.62 \pm 98.65 \mathrm{~N})$.

2- The grinding machine can be manufactured and used to grinding the local mango kernel at the feeding quantity of $20 \mathrm{~kg}$, drum speed of 2000 and knives number of 36 to obtain the homogeneous size distribution with less "CV" of 4.3, 11.22 and $12.26 \%$ respectively and at these studied parameters the MWD, machine productivity, power consumed and specific energy requirement are $1.309 \mathrm{~mm}, 2.94 \mathrm{Mg} / \mathrm{h}, 3.60 \mathrm{~kW}$ and $1.22 \mathrm{~kW} . \mathrm{h} / \mathrm{Mg}$, respectively.

3- The developed grinding machine which manufacture from a locally materials can be tested to grind many solid wastes to increase the developed grinding machine reliability.

\section{REFERENCES}

Aly, L.H.M. and Dimian, T.F. (1988). Equipments of animal production mechanization. Baghdad Univ. 231 - 259.

AOAC (2000). Official methods of analysis of AOAC international .17th Ed. official method of analysis, INC, suite 500 William Horwitz, 208772417 USA., pp 1-26. 
Aregheor, E.M. (1998). A review of implications of anti-quality and toxic components in unconventional feedstuffs for use in intensive animal production in Nigeria. Veterinary and Human Toxicology. 40 (1): 35-39.

ASAE Standards (2001). ASAE S 368. Compression test of food material of convex shape, st. Joseph, MI: ASAE.

Ashoush, I.S. and Gad-Allah, M.G.E. (2011). Utilization of mango peels and seed kernels powders as sources of phyto-chemicals in biscuit. World J. of Dairy \& Food Sci., 6 (1): 35-42.

Campbell, G.M. (2007). Roller milling of wheat. In Salman, A.D. Ghadiri, M. and Hounslow, M.J. (eds.), Handbook of Particle Breakage, (Oxford, UK: Elsevier), 391-428.

Central Administration foe Agricultural Economics and statistics, Ministry Agricultural, Egypt, 2010

Deaton. U.W.; Lott, B.D. and Simmons, J.D. (1989). Hammer mill versus roller mill grinding of corn for commercial layers. Poultry. Sci., 68: 1342-1344.

Diarra, S.S.; Saleh, B.; Kwari; Usman, B.A. and Igwebuike, J.U. (2011). Evaluation of boiled mango kernel meal as energy source by broiler chickens in the semi-arid zone of Nigeria. I.J.S.N., Vol. 2 (2): 270- 274.

El-Ashhab, A.O.M; Hemeda, B.E.; Radwan, H.A. and Deraz, T.A.A. (2003). Minimizing energy required to grind some grains for feed rations. The 9th Conf. of Egyptian Soc. of Nutrition and Feeds. 13251331.

El-Dorghamy, A. (2010). Biogas potential in Egypt. Tri-Ocean Carbon \& Renewables., P. 1-25.

El-Hadidi, Y.M.; Amin, E.A. and Hegazy, K.E. (1997). Performance evaluation for some types of crushing machines used in poultry farms. Misr. J. Ag. Eng., 14(3): 285 - 298. 
FAO (2006). Small mills in Africa selection, installation and operation of equipment. At the web page: http://www.fao.org/faostat/.

Fife, T.D.; Bohnert, R.M. and Bowman, J. (2010). Factors to consider when feeding grain supplement to beef cattle. Cattle producers library, 332-1: 332-4.

Hall, C.W. and Davis, D.C. (1979). Processing equipment for agricultural products. $2^{\text {nd }}$ Ed. AVI pub. INC., Ch. 1, 1 - 31.

Ibrahim, M.K. (1982). Wet milling of wheat grain. M. Sc. Thesis Fac. of Agric., Mansoura Univ., Egypt.

Kim, H.; Moon, J.Y.; Kim, H.; Lee, D.S.; Cho, M. and Cho, H.K. (2010). Antioxaidant and antiproliferative activities of mango (Mangifera indica) flesh and peel. Food Chem.,121: 429-436.

Mahmoued, H.A. (2005). Biochemical evaluation of some agricultural byproducts and their application in animal feeds. Ph. D., Thesis. Agric. Sci. Det. Ain Shams Univ. 70-78p

Maisuthisakul, P. and Gordon, M.H. (2009). Antioxidant and tyrosinase inhibitory activity of mango seed kernel product. Food Chemistry 117: 332-341.

McCabe, W.L.; Smith, J.C. and Harriott, P. (1993). Unit operations of chemical engineering. Mechanical separation, Me Graw-Hill, Inc. New York, USA.

Ministry of Agriculture and Land Reclamation, Economic Affalrs Sector (EAS) (2012). Study of the indicators agricultural statistics Egypt.

Mohsenin, N. (1998). Physical properties of plant and animal materials. Gordon and Breach Pub. Inc., Amsterdam, Netherlands. 
Naveen, Z.; Prasad, J.R. and Rao, Z.P. (2006). Chemical composition and in vitro dry matter digestibility of some fruit wastes. Tamilnadu J. Vet. Anim. Sci., 2, 229-233.

RNAM (1983). RNAM test codes and procedures for farm machinery. Technical Series No. 12.

Seyed M.A.R. and M. Elnaz (2006). Some physical properties of the watermelon seeds. African Journal of Agricultural Research Vol. 1 (3), pp. 065-069.

Soong, Y. and Barlow, P.J. (2006). Quantification of gallic acid and ellagic acid from Longan (Dimocaepus longan Lour) seed and mango (Mangifera indica L.) kernel and their effects on antioxidant activity. Food Chemistry, 97: 524-530.

Sun, Y. (2002). Enzymatic hydrolysis of rye straw and bermudagrass for ethanol production. $\mathrm{PhD}$ diss. Raleigh, N.C.: North Carolina State University, Department of Biological and Agricultural Engineering.

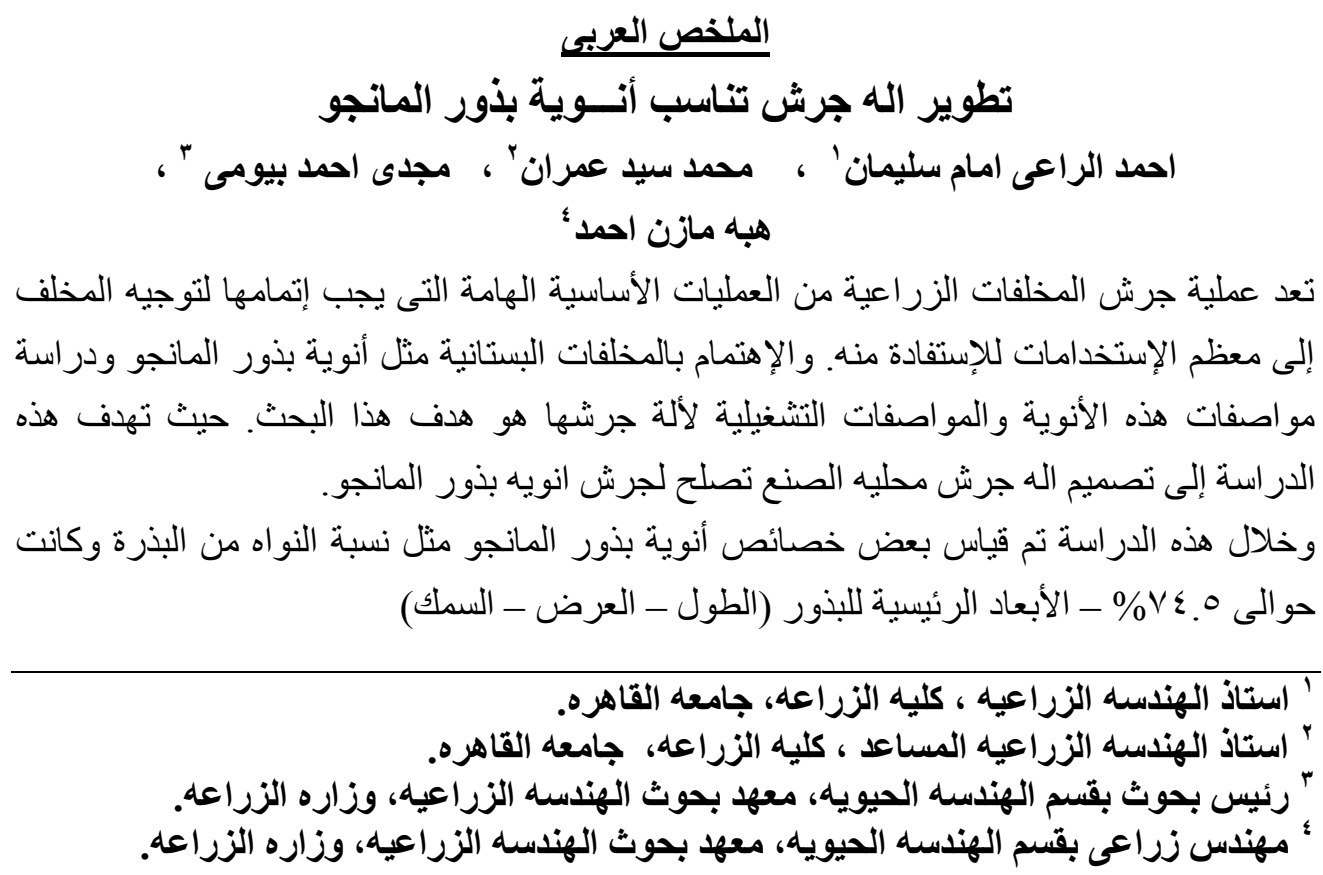

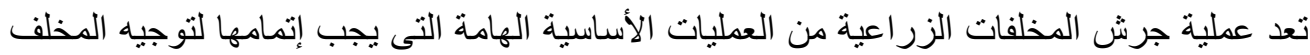

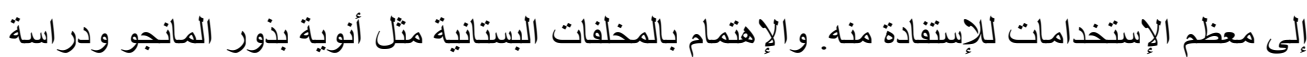
مواصفات هذه الأنوية و المواصفات التثغيلية لألة جرشها هو هدف هذا البحث. حيث تهدف هذه

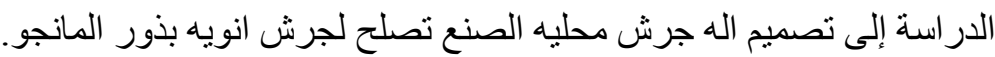
وخلال هذه الدراسة تم قياس بعض خصائص أنوية بذور المانجو مثل نسبة النو اه من البذرة وكانت

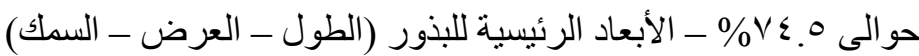
' استاذ الهندسه الزراعيه ، كليه الزراعه، جامعه القاهره.

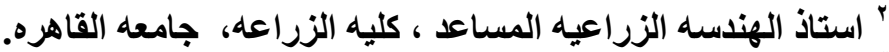

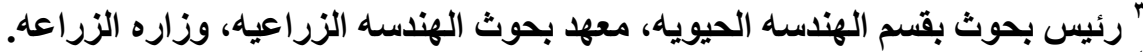
" مهندس زراعى بقسم الهندسه الحيويه، معهل بحوث الهندسه الزراعيه، وزاعيه وزاره الزراعه. 


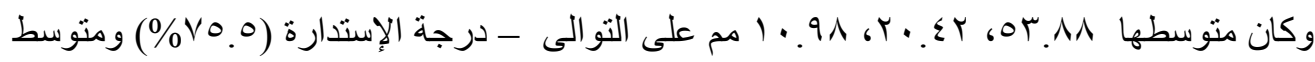

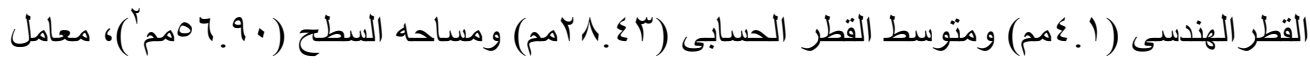

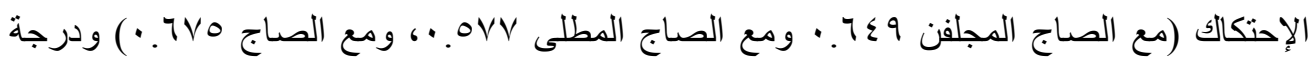

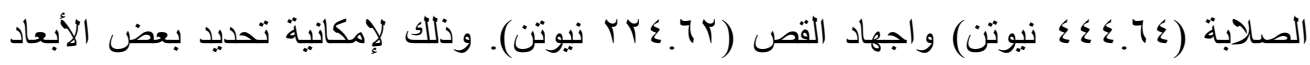

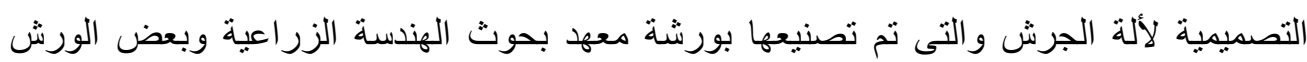

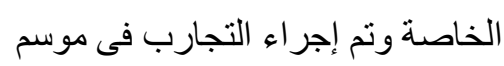

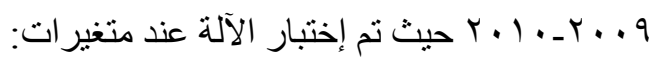
1 - كمية البذور • (10، 10، · ب كيلوجر ام.

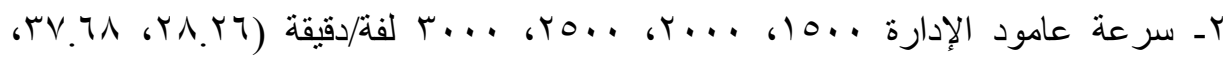

$$
\text { (ث/. }
$$

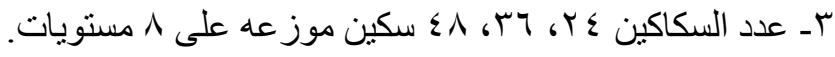

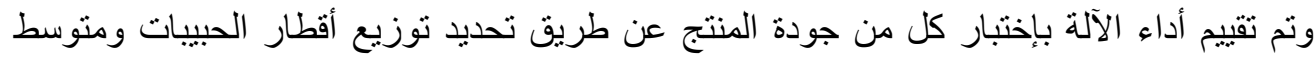

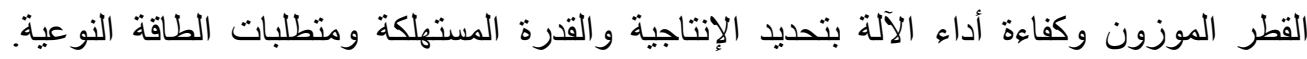

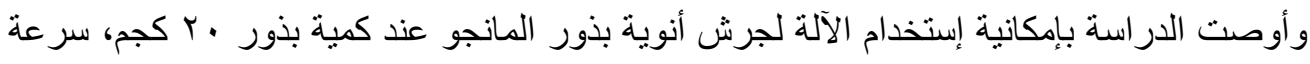

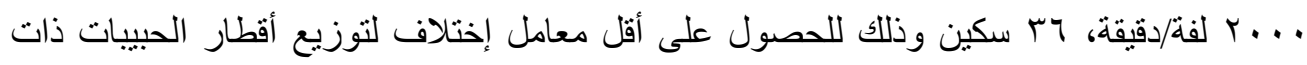

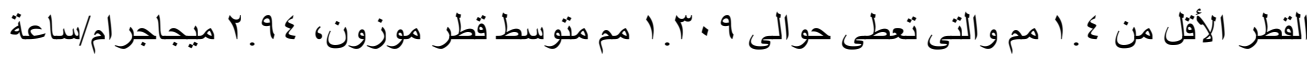

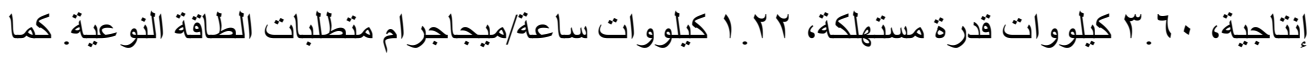

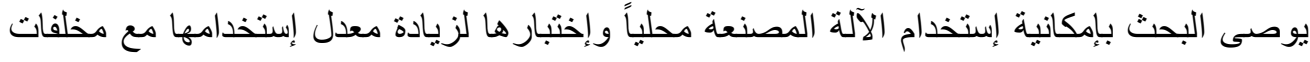
أخرى. 